\title{
Lead isotope ratios as tool for elucidation of chemical environment in a system of Macrolepiota procera (Scop.) Singer - soil
}

\author{
Slađana Đurđić ${ }^{~}$. Vesna Stanković ${ }^{2}$ S Slavica Ražić ${ }^{3}$ Jelena Mutić ${ }^{1,4}$
}

Received: 5 December 2019 / Accepted: 29 January 2020

(C) Springer-Verlag GmbH Germany, part of Springer Nature 2020

\begin{abstract}
The analysis of isotope ratios of lead in the mushrooms and soil, where they were grown, assisted with a principal component analysis, offered a new perspective for understanding possible chemical environment in a real setup of those compartments. The content of lead and its isotope compositions were determined in soil samples and mushroom Macrolepiota procera from unpolluted area of Mountain Goč, Serbia. Sequential extraction procedure based on the Commission of the European Community Bureau of Reference (BCR) was applied on soil samples in order to determine the distribution of lead in the labile and un-labile fractions of the soil. Caps and stipes of mushrooms were subjected to microwave acid-assisted digestion prior to measurements by inductively coupled plasma quadrupole mass spectrometer for determination of lead content and lead isotope ratios. Information about the chemical fractionation of $\mathrm{Pb}$ in soil, $\mathrm{Pb}$ isotopic data from soil fractions and fruiting bodies allowed a more detailed insight on the uptake mechanisms. Lead was predominantly associated with reducible fraction $(\sim 60 \%)$. Only its small portion $(\sim 1 \%)$ was present in the exchangeable and acid-extractable fractions suggesting the low mobility of Pb. Lead isotope analysis revealed the presence of anthropogenic lead in the surface soil. Significant lower ${ }^{206} \mathrm{~Pb} /{ }^{207} \mathrm{~Pb}$ compared with other fractions was found in exchangeable and acid-soluble fraction $(1.331 \pm 0.010)$, which corresponds to the isotope ratio of European gasoline. The highest ${ }^{206} \mathrm{~Pb} /{ }^{207} \mathrm{~Pb}$ ratio was observed in reducible fraction $(1.162 \pm 0.007)$, while in oxidizable and residual fraction, those values were similar $(1.159 \pm 0.006$ and $1.159 \pm 0.004$, respectively). Distinction of exchangeable and acid-extractable fractions from others was also confirmed, for the first time, by principal component analysis. The analysis of four isotope ratios $\left({ }^{206} \mathrm{~Pb} /{ }^{207} \mathrm{~Pb},{ }^{208} \mathrm{~Pb} /{ }^{206} \mathrm{~Pb},{ }^{206} \mathrm{~Pb} /{ }^{204} \mathrm{~Pb}\right.$, and $\left.{ }^{207} \mathrm{~Pb} /{ }^{204} \mathrm{~Pb}\right)$ indicated that the analyzed $M$. procera accumulates lead from the first two fractions of topsoil layers.
\end{abstract}

Keywords BCR sequential extraction $\cdot$ Lead isotope ratio $\cdot$ Mushrooms $\cdot$ PCA

Responsible Editor: Philippe Garrigues

Electronic supplementary material The online version of this article (https://doi.org/10.1007/s11356-020-07947-6) contains supplementary material, which is available to authorized users.

Slavica Ražić

slavica.razic@pharmacy.bg.ac.rs

$\triangle$ Jelena Mutić jmutic@chem.bg.ac.rs

1 University of Belgrade, Faculty of Chemistry, Studentski trg 12-16, Belgrade 11000, Serbia

2 Institute of Chemistry, Technology and Metallurgy, University of Belgrade, Njegoševa 12, Belgrade 11000, Serbia

3 Faculty of Pharmacy, Department of Analytical Chemistry, University of Belgrade, Vojvode Stepe 450, Belgrade 11221, Serbia

4 Ghent University Global Campus, Incheon, South Korea

\section{Introduction}

Macrolepiota procera (Scop.) Singer, an edible mushroom belongs to Agaricaceae of Agaricales, is a saprobe. This species is widely distributed in the northern areas of Asia such as Korea, China, and Japan (Shim et al. 2005) and across the Europe (Kalač 2010; Stefanović et al. 2016; Širić et al. 2017). Saprobic fungi usually live on dead vegetable matter in forests, and they are the only multi-celled organisms which can digest the cellulose and lignin, the two major components of wood. In such way, mycorrhizal and saprobe mushrooms take part in a biogeochemical turnover of all mineral constituents in soil compartments or other substrates in which mycelium develops. Saprobic mushrooms are better accumulators of heavy metals, especially of lead, in comparison with mycorrhizal species (García et al. 1998). Lead content depended on species (i.e., genus, trophic status), and some 
species have been identified as large accumulators of this metal: Agaricus campestris (García et al. 2009; Schlecht and Säumel 2015), Agaricus macrosporus (García et al. 1998), Clitocybene bularis (García et al. 1998), Coprinus comatus (García et al. 2009), Lepista nuda (Isildak et al. 2004, 2007; Kalač and Svoboda 2000; Sesli et al. 2008), Lycoperdon perlatum (Kalač and Svoboda 2000; Sesli et al. 2008), Macrolepiota rhacodes (Kalač and Svoboda 2000; Sesli et al. 2008), and Russula delica (Tüzen 2003).

It is known that $M$. procera is a good source of minerals, especially K (Gucia et al. 2012a; Gucia et al. 2012b; Kułdo et al. 2014), Mg (Falandysz and Gucia 2008; Gucia et al. 2012a; Gucia et al. 2012b; Kułdo et al. 2014), and Se (Falandysz et al. 2008; Stefanović et al. 2016), as well as of carbohydrates, proteins, and dietary fibers (Baptista et al. 2009). On the other side, this species is also an accumulator of toxic metals such as Cd (Kalač and Svoboda 2000; Kalač 2009; Svoboda et al. 2000), Hg (Gucia and Falandysz 2003), and Pb (García et al. 1998; Kalač and Svoboda 2000; Schlecht and Säumel 2015; Sesli et al. 2008; Svoboda et al. 2000).

The uptake of metals depends primarily on mushroom species, but also on other factors, such as concentration of metals in the substrate, $\mathrm{pH}$, the amount of organic matter, and morphological part of fruiting body, development stage, age of mycelium, and interval between the fructifications (Ișıloğlu et al. 2001; Kalač et al. 1996).There is a direct relationship between $\mathrm{Pb}$ concentrations in mushrooms and soil contamination due to traffic pollution (Borovička et al. 2014; Ettler et al. 2004; Falandysz and Treu 2017; García et al. 1998; Hamelin et al. 1997).The vast majority of the wild growing mushrooms and among the species of the genera Agaricus, Macrolepiota, or Boletus accumulated extremely high amounts of lead in urban areas (Schlecht and Säumel 2015).

The uptake, transport, accumulation, and hyperaccumulation of various chemical elements and compounds in mushroom fruiting bodies create a very complex chemical environment (Falandysz and Treu 2017). Moreover, mushrooms developed the ability to dissolve the substrate where they grow, and it is very important considering microbial processes in soils because the mechanisms of solubilization or immobilization can have significant consequences for lead mobility (Sayer et al. 1999).

Lead is the most widely scattered toxic metal worldwide (Tomašević et al. 2013), and sources of lead contamination are diverse (leaded gasoline, coal combustion, metallurgical activities, waste incineration, etc.). Based only on total concentration of lead and composition of minerals, pollution source cannot be always identified (Ettler et al. 2004; Komárek et al. 2008). Lead naturally occurs in the form of four stable isotopes: ${ }^{204} \mathrm{~Pb}(1.4 \%),{ }^{206} \mathrm{~Pb}(24.1 \%),{ }^{207} \mathrm{~Pb}(22.1 \%),{ }^{208} \mathrm{~Pb}$ (52.4\%). Only ${ }^{204} \mathrm{~Pb}$ has a non-radiogenic origin, while other isotopes are produced by radioactive decay of ${ }^{238} \mathrm{U},{ }^{235} \mathrm{U}$, and ${ }^{232} \mathrm{Th}$, respectively. Abundance of $\mathrm{Pb}$ isotopes depends on the relative concentration of the primordial $\mathrm{Pb}, \mathrm{U}$, and $\mathrm{Th}$, but also on their decay processes. The profile of lead isotope ratios has been used as a "fingerprint" to identify the sources of contamination and environmental pollution (Ettler et al. 2004). Mainly, ${ }^{206} \mathrm{~Pb} /{ }^{207} \mathrm{~Pb}$ is used for the identification of contamination source with lowest analytical error (Komárek et al. 2008; Monna et al. 1995). Lead ore used for the production of antiknock additives is directly influenced to isotope composition. The gasoline from Western Europe is characterized by low ${ }^{206} \mathrm{~Pb} /{ }^{207} \mathrm{~Pb}(1.03-1.04)$, while in Central and Eastern Europe, higher values were reported (1.11-1.13) (Komárek et al. 2008). Most European countries have completely eliminated the usage of leaded gasoline by 2000 . Unfortunately, Serbia used it even to 2010. Large amounts of lead are accumulated in the soil (Emmanuel and Erel 2002; Teutsch et al. 2001). Kaste et al. (2003) concluded that more than $50 \%$ of the deposited anthropogenic lead migrated even to mineral substrate of soil. Sequential extraction has been used in analysis of the soil for decades but, although with respectable selectivity, this technique did not provide enough information on lead interaction with different soil substrates (Marin et al. 1997). The origin of the present lead and its mobility could be explained by determination of isotopic composition of fractions (Bacon et al. 2004; Emmanuel and Erel 2002).

To the best of our knowledge, there are no published data on the lead isotope ratio (LIR) in wild mushroom species such as $M$. procera, nor for any other mushroom species from Serbia. Also, there are no literature data about the LIR in soils and soil fractions as well as about their relationships with mushroom fruiting bodies. The objectives of this study were the following:(1) to establish lead isotope ratios in the fractions of soil (exchangeable, reducible, oxidizable, and residual fraction) from unpolluted Mt Goč in Serbia, using BCR sequential extraction scheme; (2) to examine isotopic composition in caps and stipes of $M$. procera mushrooms; and (3) to contribute to clarification of chemical environment in a real setup of soil-M. procera.

\section{Experimental part}

\section{Study area}

Study area was the Mountain Goč $\left(43^{\circ} 32^{\prime} 41.9^{\prime \prime} \mathrm{N} 20^{\circ}\right.$ 49' 34.0" E, altitude $1216 \mathrm{~m}$ ) located in Central Serbia (Fig. 1). This forest region consists of areas dominated by beech (Fagus moesiaca) and pine trees (Pinus nigra) (Vukojević et al. 2019). The soil type was classified as leptosol on diorite (WRB 2006). Soil was sampled in an area of $\sim 100 \mathrm{~m}^{2}$. All samples subjected to this study are listed in Table 2 . 


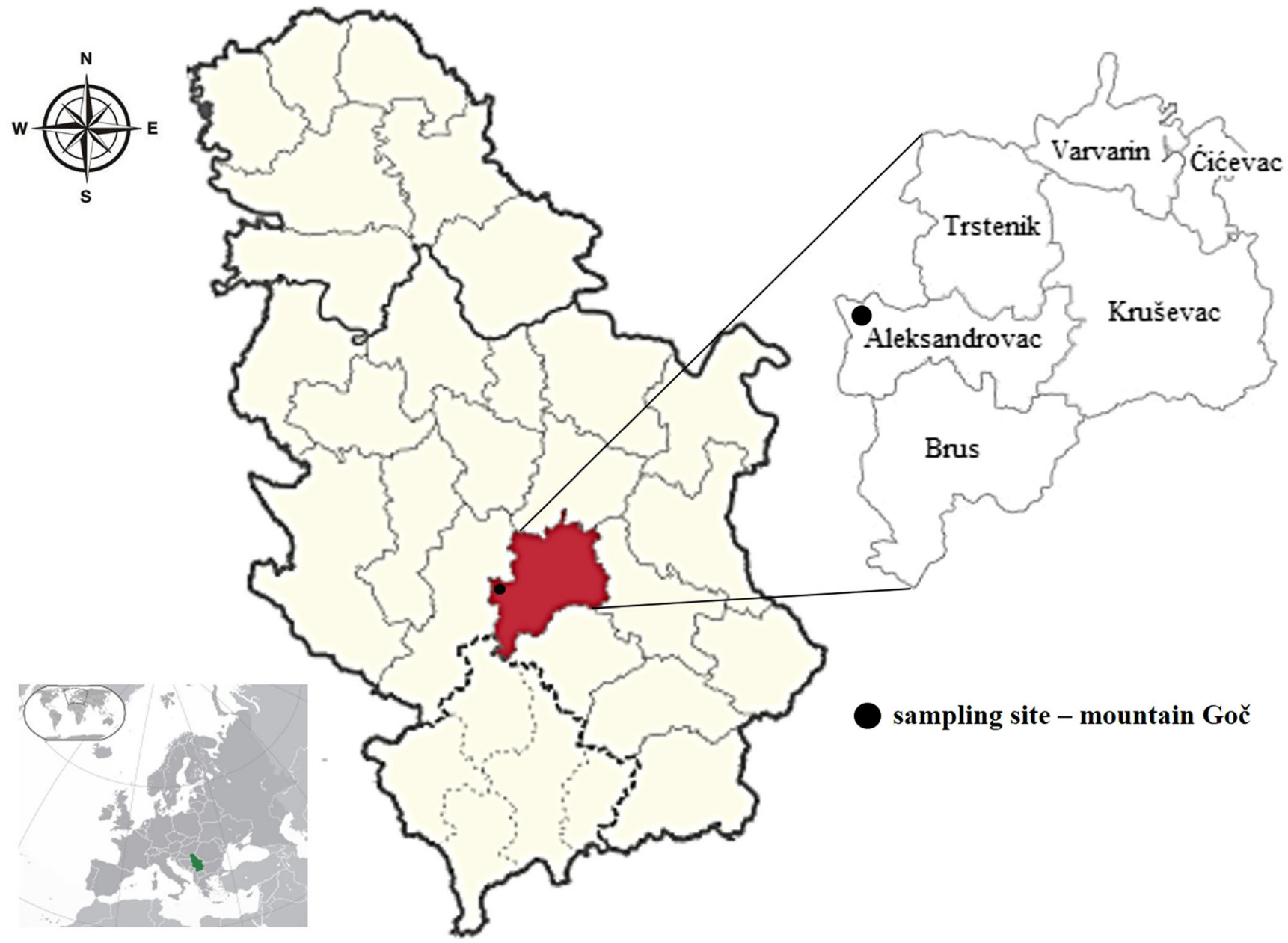

Fig. 1 Map of Serbia with location of sampling sites

\section{Soil sampling and extraction}

Surface soil samples ( $\sim 5 \mathrm{~cm}$ depth), corresponded to the $\mathrm{Au}$ horizon, were sampled at 14 locations using plastic spoons. Wood shavings and rocks were removed; the samples were packed into polyethylene bags and transported to the laboratory. After homogenization, the samples were dried to constant weight at room temperature.

Soil properties such as $\mathrm{pH}$, electrical conductivity (EC), and soil redox potential (Eh) were measured in a suspension of soil in distilled water (1:2.5) according to the standard methods (SRPS ISO 10390:2007, SRPS ISO 11265:2007, ISO 11271:2002). The organic matter content (Corg) was determined by the Walkley-Black method (De Vos et al. 2007). One gram of each sample was subjected to BCR three-stage sequential extraction procedure (Bacon et al. 2006; Rauret et al. 1999) in order to separate fractions: exchangeable and acid-extractable (F1); reducible (F2), and oxidizable (F3). The residual phase $(\mathrm{R})$ was extracted in aqua regia with $12 \mathrm{M} \mathrm{HCl}$ and $16 \mathrm{M} \mathrm{HNO}_{3}(1: 3, \mathrm{v} / \mathrm{v})$. The samples were filtered through Whatman paper (no. 42) and diluted to appropriate volume. The lead recovery of sequential extraction analysis was determined by comparison of the sum of all four fractions with the pseudo total metal concentrations. Recovery values were in the range between 90 and 105\%. For pseudo total (PT) content, $0.5 \mathrm{~g}$ of each sample was digested in aqua regia with $12 \mathrm{M} \mathrm{HCl}$ and $16 \mathrm{M} \mathrm{HNO}_{3}(3: 1, \mathrm{v} / \mathrm{v})$, at $80^{\circ} \mathrm{C}$ for $5 \mathrm{~h}$. After digestion, the samples were filtered through Whatman paper (no. 42) and diluted to $100 \mathrm{~mL}$.

\section{Mushroom sampling and digestion}

The caps of $M$. procera are characterized by an unusually large diameter $(10-30 \mathrm{~cm})$ and are an edible part of the mushroom. M. procera roughly similar in size (cap diameter) and shape (parasol-shaped) was collected and cleaned of any visible plant vegetation or soil debris. Caps and stipes were separated with plastic knife, dried, and pulverized (Gucia et al. 2012). Each composite sample of caps and stipes, consisted of one or few individuals, were collected together with one soil sample.

The dried samples were subjected to microwave digestion in microwave oven (Ethos 1, Advanced Microwave Digestion System, Milestone, Italy). For the digestion, $5 \mathrm{~mL}$ of 
concentrated $\mathrm{HNO}_{3}\left(16 \mathrm{~mol} / \mathrm{dm}^{3}\right)$ and $2 \mathrm{~mL}$ of concentrated $\mathrm{H}_{2} \mathrm{O}_{2}\left(8.8 \mathrm{~mol} / \mathrm{dm}^{3}\right)$ were used. Ramp and hold time for the temperature of $200^{\circ} \mathrm{C}$ were 10 and $15 \mathrm{~min}$, respectively. The samples were quantitatively transferred into a $50-\mathrm{mL}$ volumetric flask and diluted with ultra-pure water.

\section{Reagents and solutions}

All the used chemicals for sequential extraction, as well as nitric acid, hydrochloric acid, and hydrogen peroxide, were of analytical grade and supplied by Merck (Darmstadt, Germany). Ultra-pure water was prepared using Milli-Q system (Millipore Simplicity 185 System incorporating dual UV filters, 185 and $254 \mathrm{~nm}$ ).

Certified reference material NIST SRM 981 (Common lead isotopic standard, National Institute of Standards and Technology, USA) was performed after every two sample measurements in order to correct mass bias and dead time effects. Certified reference material NIST SRM 997 (Isotope standard for thallium, National Institute of Standards and Technology, USA) was used as an internal standard. The accuracy of the $\mathrm{Pb}$ isotope measurements was monitored by measuring the isotopic standard AGV-2 (USGS, USA). Measurement reproducibility of BCR analysis was controlled using certified reference material lake sediment BCR 701.

For isotope ratio determination, both the initial samples of mushrooms and samples obtained in each phase of sequential extraction were diluted, so that the final concentration of lead was below $40 \mu \mathrm{g} / \mathrm{L}$. Internal standard $(\mathrm{Tl})$, with final concentration of $2 \mu \mathrm{g} / \mathrm{L}$, was added to all samples.

\section{Instrumentation}

Inductively coupled plasma mass spectrometer (ICP-Q-MS, Thermo Scientific X series 2, UK) was used for measuring the concentration of lead and lead isotope ratios in soil extracts and mushroom samples. The system was controlled by Qtegra Instrument Control software. Operating conditions and mass spectrometer settings are given in Table S1 (Supplementary material).

\section{Optimization of instrumental parameters}

ICP-Q-MS has no satisfactory accuracy and precision in determining the isotope ratios of lead compared with thermal ionization mass spectrometry (TIMS) and multi-collector ICP-MS. Therefore, optimization of certain parameters is required. In order to increase the precision and sensitivity, integration time (dwell time) was optimized, while for higher accuracy, the dead time of detector was optimized, and isotope ratios were corrected on mass bias effect. Also, the corrections of intensity of ${ }^{204} \mathrm{~Pb}$ were done (Marguí et al. 2007).
For dwell time optimization, a NIST SRM 981 solution was used. Concentration of $5.12 \mu \mathrm{g} / \mathrm{L} \mathrm{Pb}$ spiked with $2 \mu \mathrm{g} / \mathrm{L}$ of $\mathrm{Tl}$ was analyzed in five replicates and six points per peak. This solution was monitored at different dwell times, and RSD of isotope ratios was measured (Encinar et al. 2001).Based on the lowest RSD, the dwell time for each isotope was optimized. RSD for ${ }^{204} \mathrm{~Pb}$ was $0.3 \%$, while for other isotopes, it was in the range of $0.10-0.15 \%$, what is in concordance with some reported data (Marguí et al. 2007). The highest dwell time had ${ }^{204} \mathrm{~Pb}(0.100 \mathrm{~s})$ due to its lowest abundance in nature (Encinar et al. 2001), while the lowest was for ${ }^{208} \mathrm{~Pb}(0.005 \mathrm{~s})$. Dwell time for isotope ${ }^{206} \mathrm{~Pb},{ }^{207} \mathrm{~Pb},{ }^{203} \mathrm{Tl}$, and ${ }^{205} \mathrm{Tl}$ was $0.025 \mathrm{~s}$.

Detector has a period of time when it cannot separate two events, i.e., events could not be recorded as two separate pulses. This time is called the dead time of detector (Quétel et al. 2000). There are several available methods for its optimization (Nelms et al. 2001). In this work, the measurement of isotope ratio ${ }^{204} \mathrm{~Pb} /{ }^{208} \mathrm{~Pb}$, in the function of different concentrations of lead $(10,20$, and $30 \mu \mathrm{g} / \mathrm{L})$ at different dead times $(25,30,35,40$, and $45 \mathrm{~ns})$, was conducted for optimization of dead time (Marguí et al. 2007; Nelms et al. 2001) using the NIST SRM 981 standard. By linear fit of regression line, the dead time, independent on the applied concentrations of lead (the slope of the regression line closest to zero), was selected. Dead time was optimized at $40 \mathrm{~ns}$.

Also, it was necessary for the detector to work in a pulse mode during the determination of isotope ratios. This mode provides higher sensitivity compared with the analog mode (Marguí et al. 2007). Depending of applied concentration, the detector had the ability to change modes. Based on that above, pulse mode of detector was used for the determination of lead isotope ratios, in working range of the lead concentration of $1-40 \mu \mathrm{g} / \mathrm{L}$.

Mass discrimination (mass bias) occurs because of differential transfer of ions from the sampling system, through the plasma and mass analyzer, to the detector. This phenomenon is a characteristic for all ICP-Q-MS devices and can cause the deviations from the true value up to several percentage per mass unit in analysis of isotope ratios (Marguí et al. 2007). Therefore, it is necessary to correct the obtained values of isotope ratios for the mass bias effect.

In that order, internal and external correction can be applied (Almeida and Vasconcelos, 1999, 2001; Larcher et al. 2003; Marguí et al. 2007). NIST SRM 997 was used as an internal standard for thallium due to the similar mass of its isotopes with lead isotopes, as well as constant isotope ratio of ${ }^{203} \mathrm{Tl}$ and ${ }^{205} \mathrm{Tl}$ (Begley and Sharp 1997; Larcher et al. 2003;Marguí et al. 2007; White et al. 2000). For external correction, NIST SRM 981 was used (Marguí et al. 2007; Vanhaecke et al. 2009). The best results were obtained by applying bracketing, when each sample precedes and follows the standard solution 
(Vanhaecke et al. 2009). In our case, bracketing was run with standard solution containing $5.12 \mu \mathrm{g} / \mathrm{L}$ of $\mathrm{Pb}$.

For correction of the measured isotope ratios, it is necessary to calculate the bias factor, $K$ (Begley and Sharp 1997; Encinar et al. 2001; Heumann et al. 1998; Marguí et al. 2007). Bias factor can be calculated using the three algorithms: linear, potential, and exponential (Encinar et al. 2001; Larcher et al. 2003; Marguí et al. 2007; Thirlwall 2002; White et al. 2000). By using the external correction and potential algorithm, the obtained ratios of standard reference material (NIST SRM 981) were in best agreement with certified standard value (Table 1) and hence, this procedure was applied in further work.

Due to the possible presence of mercury in samples, the intensity of ${ }^{204} \mathrm{~Pb}$ was corrected for the intensity of ${ }^{204} \mathrm{Hg}$ using the ${ }^{202} \mathrm{Hg}$ signal (Begley and Sharp 1997; Kamenov et al. 2004; Marguí et al. 2007; Nelms et al. 2001). The intensity of ${ }^{204} \mathrm{~Pb}$ was calculated using the following equation: ${ }^{204} \mathrm{~Pb}=I\left({ }^{204} \mathrm{~Pb}\right)-0.2290 \times I\left({ }^{202} \mathrm{Hg}\right)$, where 0.2290 is ratio of the abundance of ${ }^{204} \mathrm{Hg}$ and ${ }^{202} \mathrm{Hg}$ in nature (Kamenov et al. 2004;Marguí et al. 2007; White et al. 2000).

\section{Statistical analysis}

Descriptive statistics was carried out by a demo version of the NCSS statistical software. Principal component analysis (PCA) was performed by PLS_ToolBox, v.6.2.1, for MATLAB 7.12.0 (R2011a).

Prior to multivariate analysis, auto-scaling of the lead concentration in the fractions of sequential extraction was done, and data matrix was composed. A singular value decomposition algorithm with a 0.95 confidence level for Q and T2 Hotelling limits for outliers was used for implement of PCA. In the next step, an Eigen analysis of the correlation matrix was done. Only the first components with subsequent eigenvalues less than one are to be retained and they account for a high percentage of the determinable variance.

\section{Results and discussion}

The contents of lead obtained for each phase of BCR sequential extraction procedure and pseudo total obtained from aqua regia digestion are given in Table 2 . The distribution of lead by fractions of sequential extraction was in order as follows: exchangeable and acid extractable $<$ oxidizable $<$ residual $<$ reducible. The highest content of lead was found in the Fe-Mn oxide phase ( $65 \%$ of the pseudo total lead content) what is in agreement with reported data. Bacon et al. (2006) analyzed the soil near Glensaugh Research Station using modified BCR sequential extraction and obtained similar results for $\mathrm{Pb}$ in reducible fraction $(65-67 \%)$. Similar results were also found in studies of uncontaminated (Fernández et al. 2004), cultivated soil (Kaasalainen and Yli-Halla 2003), marine sediments (Yuan et al. 2004), and industrially contaminated soil (Davidson et al. 1998; Kartal et al. 2006; Nemati et al. 2011), as well as in the soil reference materials (Zemberyová et al. 2006). Binding of lead to this fraction could be explained by the fact that the Fe-Mn oxide fraction is an important scavenger of lead in the soil (Morillo et al. 2004; Wong and Li 2004). Even in the cases of different applied extraction procedures (Tessier), the results were in accordance with the abovementioned (Alborés et al. 2000; Morera et al. 2001; Wong and Li 2004).

In contaminated soil, the highest lead content was found in the oxidizable BCR sequential extraction fraction (Bacon et al. 2005; Bacon and Hewitt 2005). Similar results were obtained for lake sediment (Tokalioğlu et al. 2000) and industrial wastewater sludge (Kazi et al. 2005). The organic substance is the dominant sorbent in surface soil horizons for lead (Bäckström et al. 2004). In our study, a small percentage of lead was found in the organic fraction (3.70\%), that is in accordance with the small amount of organic matter content. Binding of lead to the residual fraction is relatively strong (around $31 \%$ of total), and it is considered non-labile lead.

The smallest amount of lead was found in exchangeable and acid-extractable (F1) fraction $(0.83 \%)$. Similar distribution of lead (F1 fraction up to $1 \%$ ) was recorded in marine sediments (Yuan et al. 2004) and in a cultivated soil (Kaasalainen and Yli-Halla 2003). A slightly higher percentage (up to 5\%), but the lowest in relation to other fractions of sequential extraction, was recorded in industrially contaminated soil (Davidson et al. 1998) and for street sediments (Kartal et al. 2006).

The obtained results for the content of lead in caps and stipes in $M$. procera are presented in Table 2. Higher content of lead was measured in the caps than in the stipes. M. procera has ability to accumulate lead (Kalač 2009, 2000; Svoboda et al. 2000). The content of lead is higher in caps (Falandysz et al. 2008; Gucia et al. 2012) or similar between parts (Falandysz et al. 2007a, 2007b). Furthermore, higher lead content in caps was also observed in cultivated mushrooms whose soil was treated with different lead concentrations (Zhang et al. 2012).
Table 1 Validation of accuracy of ICP-QMS method using NIST SRM 981

\begin{tabular}{llll}
\hline & ${ }^{208} \mathrm{~Pb} /{ }^{206} \mathrm{~Pb}$ & ${ }^{206} \mathrm{~Pb} /{ }^{204} \mathrm{~Pb}$ & ${ }^{206} \mathrm{~Pb} /{ }^{207} \mathrm{~Pb}$ \\
\hline Certified & $2.1681 \pm 0.0008$ & $16.937096 \pm 0.000037$ & $1.09333 \pm 0.00033$ \\
Found & $2.1681 \pm 0.0010$ & $16.942 \pm 0.002$ & $1.0934 \pm 0.0009$ \\
\hline
\end{tabular}


Table 2 Statistic parameters (mean \pm standard deviation (SD), min, and max) for lead content and isotope ratios in fractions of sequential extraction as well as in mushroom parts (caps and stipes)

\begin{tabular}{|c|c|c|c|c|c|c|c|c|}
\hline & & & \multirow[t]{2}{*}{$\mathrm{Pb}(\mathrm{mg} / \mathrm{kg})$} & \multicolumn{5}{|l|}{ Isotope ratios } \\
\hline & & & & ${ }^{206} \mathrm{~Pb} /{ }^{204} \mathrm{~Pb}$ & ${ }^{208} \mathrm{~Pb} /{ }^{206} \mathrm{~Pb}$ & ${ }^{207} \mathrm{~Pb} /{ }^{204} \mathrm{~Pb}$ & ${ }^{208} \mathrm{~Pb} /{ }^{204} \mathrm{~Pb}$ & ${ }^{206} \mathrm{~Pb} /{ }^{207} \mathrm{~Pb}$ \\
\hline \multirow[t]{12}{*}{ Soil } & $\mathrm{F} 1$ & Mean \pm SD & $0.217 \pm 0.107$ & $17.8 \pm 0.4$ & $2.15 \pm 0.02$ & $15.6 \pm 0.2$ & $38.1 \pm 0.5$ & $1.131 \pm 0.010$ \\
\hline & & Min & 0.045 & 17.4 & 2.13 & 15.2 & 37.4 & 1.116 \\
\hline & & Max & 0.477 & 18.3 & 2.17 & 15.9 & 38.9 & 1.151 \\
\hline & $\mathrm{F} 2$ & Mean \pm SD & $18.1 \pm 6.3$ & $18.3 \pm 0.2$ & $2.11 \pm 0.02$ & $15.6 \pm 0.3$ & $38.5 \pm 0.3$ & $1.162 \pm 0.007$ \\
\hline & & Min & 7.1 & 18.1 & 2.09 & 15.5 & 38.0 & 1.150 \\
\hline & & Max & 29.2 & 18.5 & 2.13 & 15.7 & 39.0 & 1.171 \\
\hline & F3 & Mean \pm SD & $0.980 \pm 0.529$ & $18.2 \pm 0.2$ & $2.12 \pm 0.02$ & $15.7 \pm 0.2$ & $38.5 \pm 0.4$ & $1.159 \pm 0.006$ \\
\hline & & Min & 0.045 & 18.0 & 2.09 & 15.5 & 38.0 & 1.152 \\
\hline & & Max & 1.500 & 18.4 & 2.14 & 15.9 & 39.3 & 1.168 \\
\hline & $\mathrm{R}$ & Mean \pm SD & $8.70 \pm 4.03$ & $18.2 \pm 0.2$ & $2.10 \pm 0.02$ & $15.6 \pm 0.2$ & $38.3 \pm 0.3$ & $1.159 \pm 0.004$ \\
\hline & & Min & 0.51 & 18.0 & 2.09 & 15.5 & 38.0 & 1.153 \\
\hline & & Max & 12.53 & 18.4 & 2.12 & 15.8 & 38.7 & 1.166 \\
\hline \multirow[t]{6}{*}{ Mushrooms } & Caps & Mean \pm SD & $1.629 \pm 1.862$ & $18.1 \pm 0.4$ & $2.12 \pm 0.03$ & $15.7 \pm 0.3$ & $38.5 \pm 0.7$ & $1.155 \pm 0.009$ \\
\hline & & Min & 0.115 & 17.2 & 2.09 & 15.1 & 36.7 & 1.132 \\
\hline & & Max & 6.653 & 18.5 & 2.16 & 16.0 & 39.8 & 1.177 \\
\hline & Stipes & Mean \pm SD & $0.709 \pm 0.702$ & $18.0 \pm 0.4$ & $2.14 \pm 0.02$ & $15.7 \pm 0.4$ & $38.6 \pm 0.9$ & $1.150 \pm 0.009$ \\
\hline & & Min & 0.036 & 17.4 & 2.12 & 15.1 & 37.1 & 1.126 \\
\hline & & Max & 2.475 & 18.6 & 2.18 & 16.3 & 39.9 & 1.177 \\
\hline
\end{tabular}

All the measured lead isotope ratios for soil fractions are given in Table 2. The lowest values of ${ }^{206} \mathrm{~Pb} /{ }^{204} \mathrm{~Pb}$ and ${ }^{208} \mathrm{~Pb} /{ }^{204} \mathrm{~Pb}$ were found in $\mathrm{F} 1$, while in other fractions, they were very similar. The ratio ${ }^{207} \mathrm{~Pb} /{ }^{204} \mathrm{~Pb}$ was similar in all fractions, which could be expected as the content of isotope ${ }^{207} \mathrm{~Pb}$ changes slightly with time in comparison with other isotopes formed by radioactive decays of $\mathrm{U}$ and Th (Komárek et al. 2008).

The lowest ${ }^{206} \mathrm{~Pb} /{ }^{207} \mathrm{~Pb}(1.131 \pm 0.010)$ and highest ${ }^{208} \mathrm{~Pb} /{ }^{206} \mathrm{~Pb}(2.15 \pm 0.02)$ values were observed for $\mathrm{F} 1$. The low ${ }^{206} \mathrm{~Pb} /{ }^{207} \mathrm{~Pb}$ in the surface soil is strong indicator for anthropogenic lead in the soil (Wong and Li 2004). Moreover, a low ${ }^{206} \mathrm{~Pb} /{ }^{207} \mathrm{~Pb}$ in exchangeable and acid-extractable fraction of surface soil leads to the same conclusion (Bacon and Hewitt 2005). In this fraction, the lead is poorly bounded, so there is an easy change of anthropogenic lead for the natural (Emmanuel and Erel 2002). In Fig. 2, the plot of ${ }^{208} \mathrm{~Pb} /{ }^{206} \mathrm{~Pb}$ vs. ${ }^{206} \mathrm{~Pb} /{ }^{207} \mathrm{~Pb}$ shows a clear distinction between the results for different samples reported in the literature (Ettler et al. 2004; Hamelin et al. 1997; Novák et al. 2003; Teutsch et al. 2001) and our research. Our data for F1 fraction were similar to those reported by Ettler et al. (2004). European gasoline is characterized by a low ${ }^{206} \mathrm{~Pb} /{ }^{207} \mathrm{~Pb}$ and a high ${ }^{208} \mathrm{~Pb} /{ }^{206} \mathrm{~Pb}$ in comparison with anthropogenic pollution originating from lead metallurgy and ore processing (Bacon et al. 2006; Ettler et al. 2004). Obviously, isotope ratios $\left({ }^{208} \mathrm{~Pb} /{ }^{206} \mathrm{~Pb}\right.$ vs. ${ }^{206} \mathrm{~Pb} /{ }^{207} \mathrm{~Pb}$ ) could indicate the most significant differences between polluted and unpolluted areas (Monna et al. 1998).
The plots of ${ }^{208} \mathrm{~Pb} /{ }^{206} \mathrm{~Pb}$ vs. ${ }^{206} \mathrm{~Pb} /{ }^{207} \mathrm{~Pb}$ and ${ }^{207} \mathrm{~Pb} /{ }^{204} \mathrm{~Pb}$ vs. ${ }^{206} \mathrm{~Pb} /{ }^{204} \mathrm{~Pb}$ for all fractions are presented in Fig. 3. The separation of $\mathrm{F} 1$ fraction is observed due to low ${ }^{206} \mathrm{~Pb} /{ }^{207} \mathrm{~Pb}$, probably originated from the former use of lead gasoline. On another hand, ${ }^{206} \mathrm{~Pb} /{ }^{207} \mathrm{~Pb}$ from residual fraction $(\mathrm{R})$ was closer to the natural lead (Fig.2). Further confirmation of anthropogenic pollution in $\mathrm{F} 1$ was indicated with plot ${ }^{207} \mathrm{~Pb} /{ }^{204} \mathrm{~Pb}$ vs. ${ }^{206} \mathrm{~Pb} /{ }^{204} \mathrm{~Pb}$.

The highest variability between different reservoirs exhibits ${ }^{206} \mathrm{~Pb} /{ }^{207} \mathrm{~Pb}$ ratio, and it is preferred by several authors

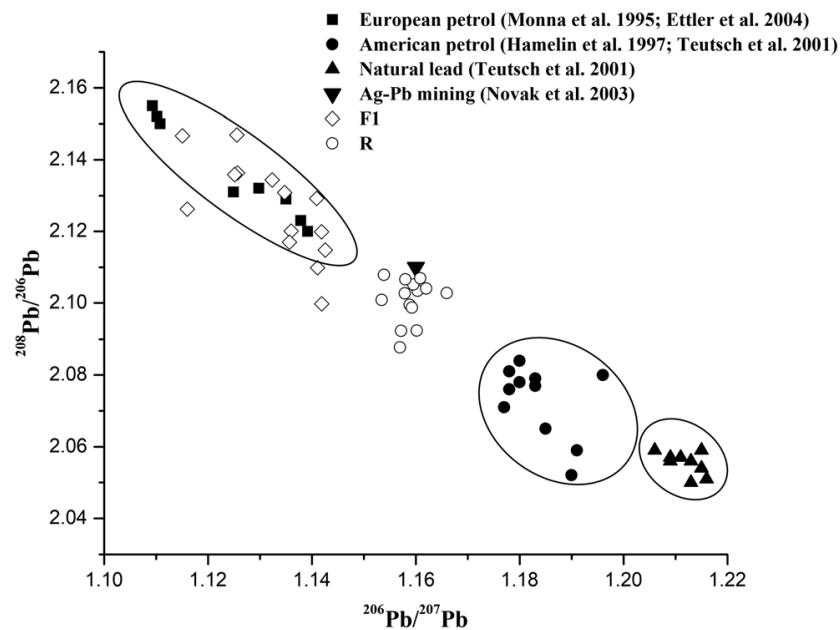

Fig. 2 Plot of ${ }^{208} \mathrm{~Pb} /{ }^{206} \mathrm{~Pb}$ vs ${ }^{206} \mathrm{~Pb} /{ }^{207} \mathrm{~Pb}$. Experimental data compared with those from literature 

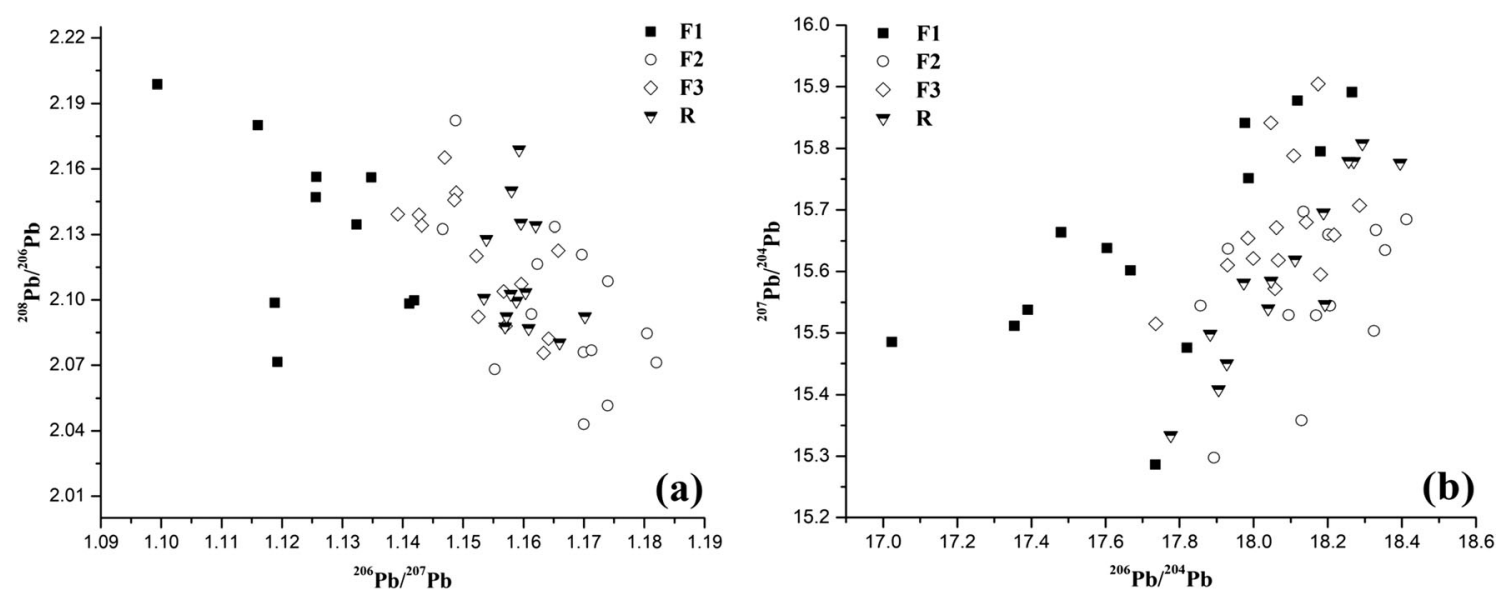

Fig. 3 Plots of ${ }^{208} \mathrm{~Pb} /{ }^{206} \mathrm{~Pb}$ vs. ${ }^{206} \mathrm{~Pb} /{ }^{207} \mathrm{~Pb}(\mathbf{a})$ and ${ }^{207} \mathrm{~Pb} /{ }^{204} \mathrm{~Pb}$ vs. ${ }^{206} \mathrm{~Pb} /{ }^{204} \mathrm{~Pb}$ (b) for exchangeable and acid-extractable (F1), reducible (F2), oxidizable (F3), and residual (R) fractions in the soil

(Komarek et al. 2007). The overlapping of the F2, F3, and R, especially F3 and R, was observed in Fig. 3 and b. The same ratio of ${ }^{206} \mathrm{~Pb} /{ }^{207} \mathrm{~Pb}$ in $\mathrm{F} 3$ and $\mathrm{R}(1.159 \pm 0.006$ and $1.159 \pm$ 0.004 , respectively) could be the result of isotopic homogeneity in fixed soil fractions (Bacon et al. 2006; Teutsch et al. 2001). In addition, the high ${ }^{206} \mathrm{~Pb} /{ }^{207} \mathrm{~Pb}$ of residual fraction could indicate the presence of geogenic lead (Bacon et al. 2006; Komárek et al. 2008).

The ${ }^{206} \mathrm{~Pb} /{ }^{207} \mathrm{~Pb}$ ratio in residual fraction was $1.159 \pm$ 0.004 and did not correspond to the real ratio which is characteristic of the natural lead $(>1.18)$, as we analyzed surface soil layer $(0-5 \mathrm{~cm})$. The ${ }^{206} \mathrm{~Pb} /{ }^{207} \mathrm{~Pb}$ ratio increases with depth of soil but the value is constant up to $5 \mathrm{~cm}$ (Borovička et al. 2014) or up to $9 \mathrm{~cm}$ (Bacon and Hewitt 2005; Wong and $\mathrm{Li}$ 2004). Furthermore, the measured ${ }^{206} \mathrm{~Pb} /{ }^{207} \mathrm{~Pb}$ values were independent on the extraction/digestion method employed in lower mineral horizons (0-9 cm) (Komárek et al. 2006). Similar results were recorded for the surface soil of Hong Kong (Wong and Li 2004) where ${ }^{206} \mathrm{~Pb} /{ }^{207} \mathrm{~Pb}$ in the residual fraction was $1.15 .{ }^{206} \mathrm{~Pb} /{ }^{207} \mathrm{~Pb}$ in residual fraction of surface
Scottish soil was 1.1571-1.1675 (Bacon and Hewitt 2005), and it was similar to our results. Both research groups found that ${ }^{206} \mathrm{~Pb} /{ }^{207} \mathrm{~Pb}$ ratio was increased with depth.

The isotope ratio ${ }^{207} \mathrm{~Pb} /{ }^{204} \mathrm{~Pb}$ was similar in easily soluble, reducible, oxidizable, and residual fractions $(15.6 \pm 0.2,15.6$ $\pm 0.3,15.7 \pm 0.2$, and $15.6 \pm 0.2$, respectively, Table 2 ). A similar trend was observed with the isotope ratio of ${ }^{206} \mathrm{~Pb} /{ }^{204} \mathrm{~Pb}$, in reducible, oxidizable, and residual fractions $(18.3 \pm 0.2$, $18.2 \pm 0.2$, and $18.2 \pm 0.2$, respectively). Slightly lower values were obtained in easily soluble fraction $(17.8 \pm 0.4)$. Furthermore, low ${ }^{206} \mathrm{~Pb} /{ }^{204} \mathrm{~Pb}$ ratio was similar to the obtained values from exhaust car gases (17.74-17.88), reported by Hansmann and Köppel (2000).

PCA confirmed clear differentiation of F1 from F2, and other fractions (Fig. 4). To the best of our knowledge, it was the first time for PCA to be applied on the isotope ratios of lead in environmental samples. The scores plot (Fig. 4a) shows clear separation of F1 from F2 along the PC1 component. The isotope ratio ${ }^{208} \mathrm{~Pb} /{ }^{206} \mathrm{~Pb}$ was responsible for separation of $\mathrm{F} 1$, while ${ }^{206} \mathrm{~Pb} /{ }^{207} \mathrm{~Pb}$ and ${ }^{206} \mathrm{~Pb} /{ }^{204} \mathrm{~Pb}$ were (a)

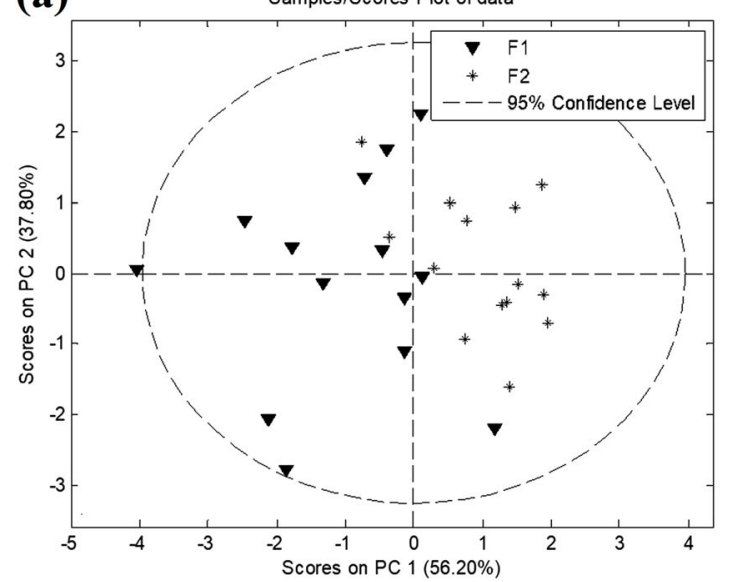

(b)

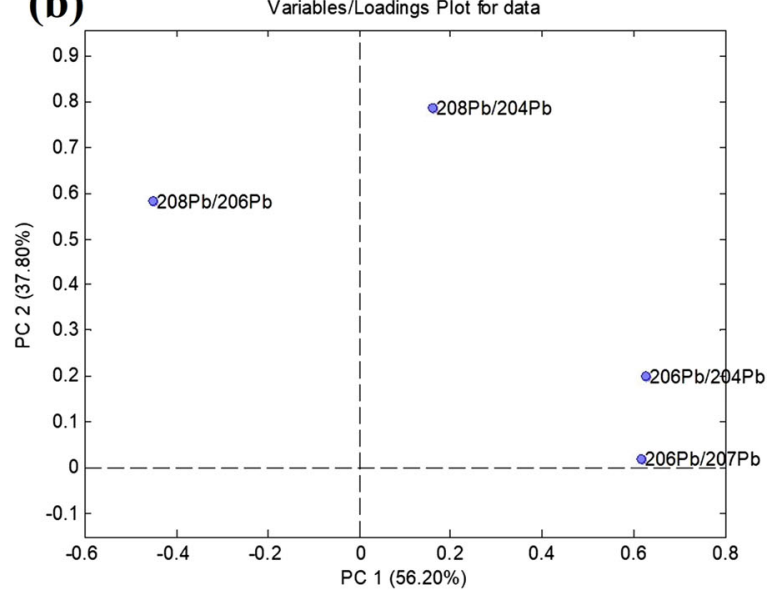

Fig. 4 Separation between F1 and F2 by PCA. a Scores plot. b Loading plot 

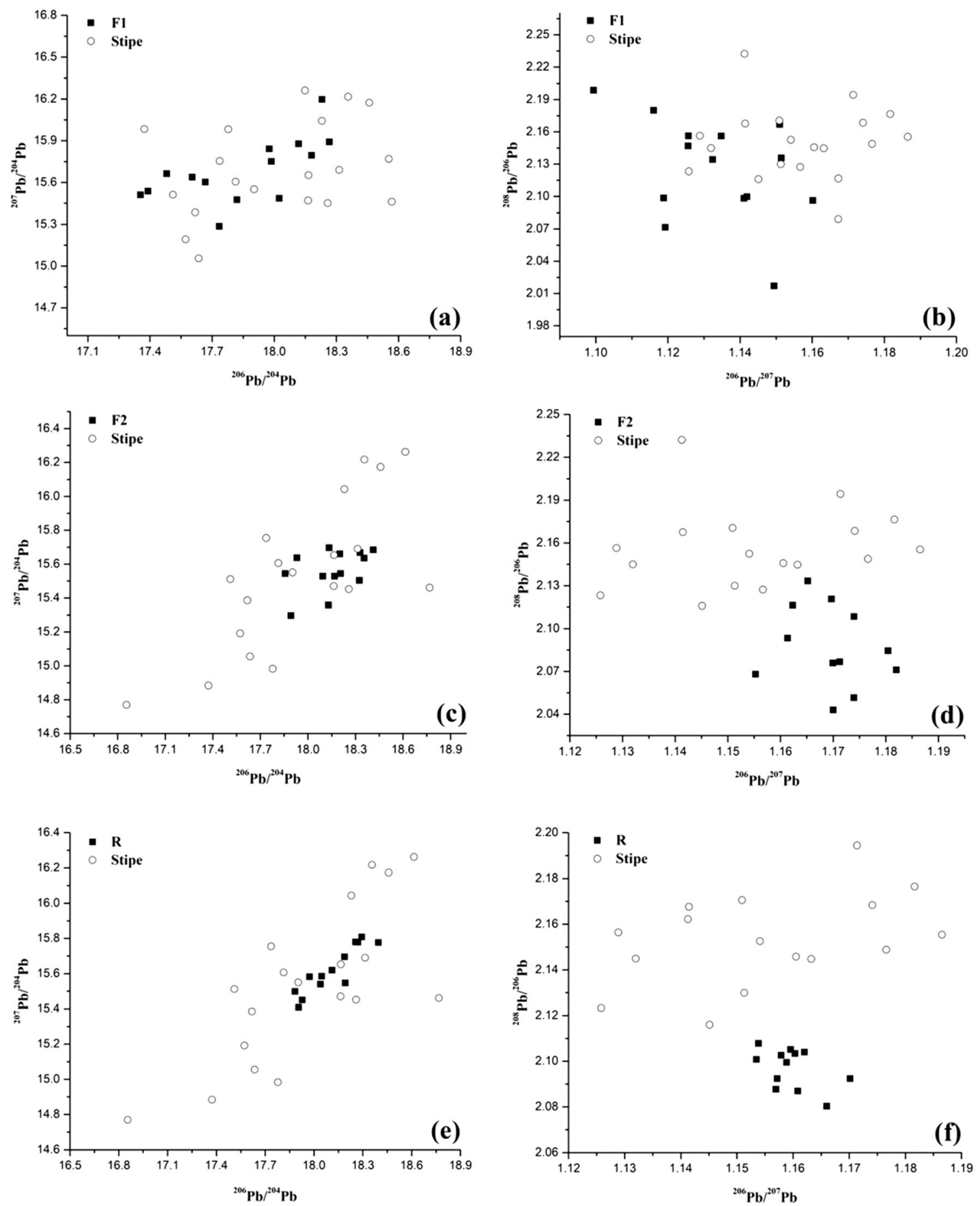

Fig. 5 Plots ${ }^{207} \mathrm{~Pb} /{ }^{204} \mathrm{~Pb}$ vs. ${ }^{206} \mathrm{~Pb} /{ }^{204} \mathrm{~Pb}$ and ${ }^{208} \mathrm{~Pb} /{ }^{206} \mathrm{~Pb}$ vs. ${ }^{206} \mathrm{~Pb} /{ }^{207} \mathrm{~Pb}$ for stipes and exchangeable and acid-extractable fraction, F1 (a, b), Fe-Mn oxides fraction, F2 (c, d), and residual, $\mathrm{R}(\mathbf{e}, \mathbf{f})$

responsible for clear separation of F2 (Fig. 4b). The different isotopic composition of ${ }^{206} \mathrm{~Pb} /{ }^{207} \mathrm{~Pb}$ in $\mathrm{F} 1(1.131 \pm 0.010)$ and F2 fraction $(1.162 \pm 0.007)$ can be explained by isotopic heterogeneity (Emmanuel and Erel 2002; Kamenov et al. 2004). The highest ${ }^{206} \mathrm{~Pb} /{ }^{207} \mathrm{~Pb}$ was in $\mathrm{Fe}-\mathrm{Mn}$ oxide fraction (Table 2) which is in an agreement with the results obtained for mountain soil from the Czech Republic (Emmanuel and Erel 2002) and Scottish upland soils (Bacon et al. 2004). This can be explained by the assumption that anthropogenic pollution remained in the most labile fraction and did not penetrate in other soil fractions.

All analyzed isotope ratios from caps and stipes are presented in Table 2. Saprotrophic fungi such as M. procera feed on decomposition of organic matter which is mostly 
accumulated in surface soil horizons and they are restricted to the upper horizons in forest soils (Luis et al. 2005). Based on lead isotope ratios in stipes and the two most available fractions of soil (F1 and F2), an attempt to elucidate a possible mechanism of action of $M$. procera on degradation of soil components was made.

Isotope ratios ${ }^{208} \mathrm{~Pb} /{ }^{206} \mathrm{~Pb}$ vs. ${ }^{206} \mathrm{~Pb} /{ }^{207} \mathrm{~Pb}$ and isotope ${ }^{204} \mathrm{~Pb}$ were considered for determination of anthropogenic pollution in mushrooms (Bacon et al. 2004). An overlap of isotope ratios for easily soluble fraction (F1) and stipes was noticed (Fig. 5a). Similar overlapping of F1 and stipes could be seen on the plot of ${ }^{208} \mathrm{~Pb} /{ }^{206} \mathrm{~Pb}$ vs. ${ }^{206} \mathrm{~Pb} /{ }^{207} \mathrm{~Pb}$ (Fig.5b). Based on the obtained results, it can be concluded that the mushroom accumulated primarily anthropogenic lead, as easily available. Komárek et al. (2007) found identical ${ }^{206} \mathrm{~Pb} /{ }^{207} \mathrm{~Pb}$ ratio in young stipes to the ratio found in the exchangeable F1 fraction of soil. But, during the growth, the uptake of $\mathrm{Pb}$ from other fractions can happen and cause the different $\mathrm{Pb}$ isotopic ratio in older fruiting body. Polysaccharides and pigments in the mycelium of mushrooms could be responsible for lead accumulation (Choma et al. 2018). These compounds are reported as strong metal sorbents, while phenolic compounds, amino, and organic acids are the most responsible for the mobilization of essential and toxic metals (Gadd et al. 2012).

The shift of the ${ }^{206} \mathrm{~Pb} /{ }^{207} \mathrm{~Pb}$ ratio to higher values and a slight overlap of F2 and stipes might indicate mixing of F1 and F2 fractions (Fig. 5c). As aforementioned, the lead is adsorbed on iron and manganese oxides. The mechanism of fungal oxidation of manganese and iron is probably nonenzymatic and involves certain metabolic products, such as citrate, gluconate, lactate, or malate (Ehrlich and Newman 2009). The obtained results of isotope ratios showed that M. procera can dissolve Fe-Mn oxides but it has no ability for decomposition of minerals. This is confirmed by considering the same isotope ratios in the residual fraction (Fig. 5ef). The decomposition of minerals by mushroom can be biomechanical and biochemical, expecting a greater effect with latter one. The mechanism was based on the release of organic acids (oxalic and citric acid) by the mushroom, changing a chemical environment, where complexes with metals from minerals are formed (Gadd 2007). However, this effect is not strong enough to destroy minerals (Gadd et al. 2012).

\section{Conclusion}

The analysis of isotope ratios of lead in the mushrooms and soil, where they were grown, assisted with a principal component analysis, offered a new perspective for understanding possible chemical environment in a real setup of those compartments. The use of BCR sequential extraction revealed fractionation of $\mathrm{Pb}$ in surface soil from Mountain Goč. The fraction of $\mathrm{Fe}-\mathrm{Mn}$ oxides had the highest content of $\mathrm{Pb}$, since these oxides act as scavenger of lead in the soil. Then, it gradually decreases as follows: residual $>$ organic matter and sulfide fraction $>$ exchangeable and acid-extractable fraction. Considering the isotope ratios, which indicate the most significant differences between polluted and unpolluted areas $\left({ }^{208} \mathrm{~Pb} /{ }^{206} \mathrm{~Pb}\right.$ vs. $\left.{ }^{206} \mathrm{~Pb} /{ }^{207} \mathrm{~Pb}\right)$, the separation of $\mathrm{F} 1$ was noticed. The anthropogenic lead in F1 probably originated from the former use of lead gasoline. On another hand, ${ }^{206} \mathrm{~Pb} /{ }^{207} \mathrm{~Pb}$ from residual fraction $(\mathrm{R})$ was closer to the natural lead. Since the soil was not analyzed in depth, it could not be claimed that anthropogenic pollution penetrated the other fractions.

A clear distinction of exchangeable and acid-extractable fractions from others was also confirmed, for the first time by principal component analysis. The analysis of four isotope ratios ${ }^{206} \mathrm{~Pb} /{ }^{207} \mathrm{~Pb},{ }^{208} \mathrm{~Pb} /{ }^{206} \mathrm{~Pb},{ }^{206} \mathrm{~Pb} /{ }^{204} \mathrm{~Pb}$, and ${ }^{207} \mathrm{~Pb} /{ }^{204} \mathrm{~Pb}$ ) indicated that the analyzed $M$. procera accumulates lead from the first two fractions of topsoil layers, characterized by low ${ }^{206} \mathrm{~Pb} /{ }^{207} \mathrm{~Pb}$ isotopic ratios, corresponded to gasoline-derived $\mathrm{Pb}$ from traffic emissions. Based on isotope ratios, it could be concluded that the mushroom adopted primarily anthropogenic lead, as anthropogenic lead also belongs to an easily available lead (F1) but unable to adopt lead from fraction of $\mathrm{Fe}-\mathrm{Mn}$ oxides neither from residual fraction.

Funding information This research was financially supported by the Ministry of Education, Science and Technological Development of the Republic of Serbia, project nos. 172030 and III43009.

\section{References}

Alborés AF, Cid BP, Gómez EF, López EF (2000) Comparison between sequential extraction procedures and single extractions for metal partitioning in sewage sludge samples. Analyst 125(7):1353-1357. https://doi.org/10.1039/b001983f

Almeida RCM, Vasconcelos MTSD (1999) Determination of lead isotope ratios in port wine by inductively coupled plasma mass spectrometry after pre-treatment by UV-irradiation. Anal Chim Acta 396(1):4553. https://doi.org/10.1016/S0003-2670(99)00356-6

Almeida CM, Vasconcelos MTSD (2001) ICP-MS determination of strontium isotope ratio in wine in order to be used as a fingerprint of its regional origin. J Anal At Spectrom 16(6):607-611. https://doi. org/10.1039/b100307k

Bäckström M, Karlsson S, Allard B (2004) Metal leachability and anthropogenic signal in roadside soils estimated from sequential extraction and stable lead isotopes. Environ Monit Assess 90(1-3): 135-160. https://doi.org/10.1023/B:EMAS.0000003572.40515.31

Bacon JR, Farmer JG, Dunn SM, Graham MC, Vinogradoff SI (2006) Sequential extraction combined with isotope analysis as a tool for the investigation of lead mobilisation in soils. Application to organic-rich soils in an upland catchment in Scotland. Environ Pollut 141(3):469-481. https://doi.org/10.1016/j.envpol.2005.08. 067 
Bacon JR, Hewitt IJ (2005) Heavy metals deposited from the atmosphere on upland Scottish soils. Chemical and lead isotope studies of the association of metals with soil components. GeochimCosmochimActa 69(1):19-33. https://doi.org/10.1016/j. gca.2004.06.030

Bacon JR, Hewitt IJ, Cooper P (2004) Origin of lead associated with different reactive phases in Scottish upland soils. An assessment made using sequential extraction and isotope analysis. J Environ Monit 6(9):766-773. https://doi.org/10.1039/b405364h

Bacon JR, Hewitt IJ, Cooper P (2005) Reproducibility of the BCR sequential extraction procedure in a long-term study of the association of heavy metals with soil components in an upland catchment in Scotland. Sci Total Environ 337(1-3):191-205. https://doi.org/10. 1016/j.scitotenv.2004.06.010

Baptista P, Ferreira S, Soares E, Coelho V, Bastos ML (2009) Tolerance and stress response of Macrolepiota procera to nickel. J Agric Food Chem 57(15):7145-7152. https://doi.org/10.1021/jf902075b

Begley I, Sharp B (1997) Characterisation and correction of instrumental bias in inductively coupled plasma quadrupole mass spectrometry for accurate measurement of lead isotope ratios. J Anal At Spectrom 12(4):395-402. https://doi.org/10.1039/a605078f

Borovička J, Mihaljevič M, Gryndler M, Kubrová J, Žigová A, Hršelová H, Řanda Z (2014) Lead isotopic signatures of saprotrophic macrofungi of various origins: tracing for lead sources and possible applications in geomycology. Appl Geochem 43:114-120. https:// doi.org/10.1016/j.apgeochem.2014.02.012

Choma A, Nowak K, Komaniecka I, Waśko A, Pleszczyńska M, Siwulski M, Wiater A (2018) Chemical characterization of alkali-soluble polysaccharides isolated from a Boletus edulis (Bull.) fruiting body and their potential for heavy metal biosorption. Food Chem 266: 329-334. https://doi.org/10.1016/j.foodchem.2018.06.023

Davidson CM, Duncan AL, Littlejohn D, Ure AM, Garden LM (1998) A critical evaluation of the three-stage BCR sequential extraction procedure to assess the potential mobility and toxicity of heavy metals in industrially-contaminated land. Anal Chim Acta 363(1):45-55. https://doi.org/10.1016/S0003-2670(98)00057-9

De Vos B, Lettens S, Muys B, Deckers JA (2007) Walkley-Black analysis of forest soil organic carbon: recovery, limitations and uncertainty. Soil Use Manag 23:221-229. https://doi.org/10.1111/j.14752743.2007.00084.x

Ehrlich HL, Newman DK (2009) Geomicrobiology, fifth ed. Boca Raton.

Emmanuel S, Erel Y (2002) Implications from concentrations and isotopic data for $\mathrm{Pb}$ partitioning processes in soils. Geochim Cosmochim Ac 66(14):2517-2527. https://doi.org/10.1016/S0016-7037(02) 00863-3

Encinar JR, Alonso JIG, Sanz-Medel A, Main S, Turner PJ (2001) A comparison between quadrupole, double focusing and multicollector ICP-MS instruments. Part I Evaluation of total combined uncertainty for lead isotope ratio measurements. J Anal At Spectrom 16(4):315-321. https://doi.org/10.1039/B006145J

Ettler V, Mihaljevic M, Komárek M (2004) ICP-MS measurements of lead isotopic ratios in soils heavily contaminated by lead smelting. Tracing the sources of pollution. Anal Bioanal Chem 378(2):311317. https://doi.org/10.1007/s00216-003-2229-y

Falandysz J, Kunito T, Kubota R, Bielawski L, Mazur A, Falandysz JJ, Tanabe S (2007a) Selected elements in Brown Birch Scaber Stalk Leccinum scabrum. J Environ Sci Heal A 42(14):2081-2088. https://doi.org/10.1080/10934520701626993

Falandysz J, Kunito T, Kubota R, Brzostowski A, Justyna MA, Tanabe S (2007b) Selected elements of Poison Pax Paxillus involutus. J Environ Sci Heal A 42(8):1161-1168. https://doi.org/10.1080/ 10934520701418672

Falandysz J, Kunito T, Kubota R, Gucia M, Mazur A, Falandysz JJ, Tanabe S (2008) Some mineral constituents of parasol mushroom (Macrolepiota procera). J Environ Sci Health B 43(2):187-192. https://doi.org/10.1080/03601230701795247
Falandysz J, Gucia M (2008) Bioconcentration factors of mercury by parasol mushroom (Macrolepiota procera). Environ Geochem Health 30:121-125. https://doi.org/10.1007/s10653-008-9133-5

Falandysz J, Treu R (2017) Fungi and environmental pollution. J Environ Sci Health B 52(3):147. https://doi.org/10.1080/03601234.2017. 1261535

Fernández E, Jiménez R, Lallena AM, Aguilar J (2004) Evaluation of the BCR sequential extraction procedure applied for two unpolluted Spanish soils. Environ Pollut 131(3):355-364. https://doi.org/10. 1016/j.envpol.2004.03.013

Gadd GM (2007) Geomycology. Biogeochemical transformations of rocks, minerals, metals and radionuclides by fungi, bioweathering and bioremediation. Mycol Res 111:3-49. https://doi.org/10.1016/j. mycres.2006.12.001

Gadd GM, Rhee YJ, Stephenson K, Wei Z (2012) Geomycology. Metals, actinides and biominerals. Environ Microbiol Rep 4(3):270-296. https://doi.org/10.1111/j.1758-2229.2011.00283.x

García MA, Alonso J, Fernández MI, Melgar MJ (1998) Lead content in edible wild mushrooms in Northwest Spain as indicator of environmental contamination. ArchEnviron ConTox 34(4):330-335. https://doi.org/10.1007/s002449900326

García MÁ, Alonso J, Melgar MJ (2009) Lead in edible mushroomsLevels and bioaccumulation factors. Journal of Hazardous Materials 167(1-3):777-783

Gucia M, Falandysz J (2003) Total mercury content in parasol mushroom Macrolepiota procera from various sites in Poland. J Phys IV France 107:581-584. https://doi.org/10.1051/jp4:20030370

Gucia M, Jarzyńska G, Kojta AK, Falandysz J (2012a) Temporal variability in 20 chemical elements content of parasol mushroom (Macrolepiota procera) collected from two sites over a few years. J Environ Sci Health B 47:81-88. https://doi.org/10.1080/03601234. 2012.611433

Gucia M, Jarzyńska G, Rafał E, Roszak M, Kojta AK, Osiej I, Falandysz J (2012b) Multivariate analysis of mineral constituents of edible parasol mushroom (Macrolepiota procera) and soils beneath fruiting bodies collected from Northern Poland. Environ Sci Pollut R 19(2): 416-431. https://doi.org/10.1007/s11356-011-0574-5

Hamelin B, Ferrand JL, Alleman L, Nicolas E, Veron A (1997) Isotopic evidence of pollutant lead transport from North America to the subtropical North Atlantic gyre. GeochimCosmochim Ac 61(20):44234428. https://doi.org/10.1016/S0016-7037(97)00242-1

Hansmann W, Köppel V (2000) Lead-isotopes as tracers of pollutants in soils. Chem Geol 171(1-2):123-144. https://doi.org/10.1016/ S0009-2541(00)00230-8

Heumann GK, Gallus MS, Rädlinger G, Vogl J (1998) Precision and accuracy in isotope ratio measurements by plasma source mass spectrometry. J Anal At Spectrom 13(9):1001-1008. https://doi.org/10. 1039/a801965g

Isildak Ö, Turkekul I, Elmastas M, Tüzen M (2004) Analysis of heavy metals insome wild-grown edible mushrooms from the Middle Black Sea region. Food Chem 86:547-552. https://doi.org/10. 1016/j.foodchem.2003.09.007

Isildak Ö, Turkekul I, Elmastas M, Aboul-Enein HY (2007) Bioaccumulation of heavy metals in some wild-grown edible mushrooms. Anal Lett 40:1099-1116. https://doi.org/10.1080/ 00032710701297042

Ișiloğlu M, Yılmaz F, Merdivan M (2001) Concentrations of trace elements in wild edible mushrooms. Food Chem 73:169-175. https:// doi.org/10.1016/S0308-8146(00)00257-0

Kaasalainen M, Yli-Halla M (2003) Use of sequential extraction to assess metal partitioning in soils. Environ Pollut 126(2):225-233. https:// doi.org/10.1016/S0269-7491(03)00191-X

Kalač P, Nižnanská M, Bevilaqua D, Stašková (1996) Concentrations of mercury, copper, cadmium and lead in fruiting bodies of edible mushrooms in the vicinity of a mercury smelter and a copper 
smelter. Sci Total Environ 177:251-258. https://doi.org/10.1016/ 0048-9697(95)04850-2

Kalač P, Svoboda L (2000) A review of trace element concentrations in edible mushrooms. Food Chem 69(3):273-281. https://doi.org/10. 1016/S0308-8146(99)00264-2

Kalač P (2009) Chemical composition and nutritional value of European species of wild growing mushrooms. A review Food Chem 113(1): 9-16. https://doi.org/10.1016/j.foodchem.2008.07.077

Kalač P (2010) Trace element contents in European species of wild growing edible mushrooms. A review for the period 2000-2009. Food Chem 122(1):2-15. https://doi.org/10.1016/j.foodchem.2010.02. 045

Kamenov GD, Mueller PA, Perfit MR (2004) Optimization of mixed PbTl solutions for high precision isotopic analyses by MC-ICP-MS. J Anal At Spectrom 19(9):1262-1267. https://doi.org/10.1039/ B403222E

Kartal S, Aydin Z, Tokalioğlu S (2006) Fractionation of metals in street sediment samples by using the BCR sequential extraction procedure and multivariate statistical elucidation of the data. J Hazard Mater 132(1):80-89. https://doi.org/10.1016/j.jhazmat.2005.11.091

Kaste JM, Friedland AJ, Stürup S (2003) Using Stable and Radioactive Isotopes To Trace Atmospherically Deposited $\mathrm{Pb}$ in Montane Forest Soils. Environmental Science \& Technology 37(16):3560-3567

Kazi TG, Jamali MK, Kazi GH, Arain MB, Afridi HI, Siddiqui A (2005) Evaluating the mobility of toxic metals in untreated industrial wastewater sludge using a BCR sequential extraction procedure and a leaching test. Anal Bioanal Chem 383(2):297-304. https://doi.org/ 10.1007/s00216-005-0004-y

Komárek M, Chrastný V, Ettler V, Tlustoš P (2006) Evaluation of extraction/digestion techniques used to determine lead isotopic composition in forest soils. Analytical and Bioanalytical Chemistry 385(6):1109-1115

Komárek M, Chrastný V, Štíchová J (2007) Metal/metalloid contamination and isotopic composition of lead in edible mushrooms and forest soils originating from a smelting area. Environment International 33(5):677-684

Komárek M, Ettler V, Chrastný V, Mihaljevic M (2008) Lead isotopes in environmental sciences: a review. Environ Int 34(4):562-577. https://doi.org/10.1016/j.envint.2007.10.005

Kułdo E, Grażyna J, Gucia M, Falandysz J (2014) Mineral constituents of edible parasol mushroom Macrolepiota procera (Scop. ex Fr.) Sing and soils beneath its fruiting bodies collected froma rural forest area. Chem Pap 68:484-492. https://doi.org/10.2478/s11696-013-0477-7

Larcher R, Nicolini G, Pangrazzi P (2003) Isotope ratios of lead in Italian wines by inductively coupled plasma mass spectrometry. J Agric Food Chem 51(20):5956-5961. https://doi.org/10.1021/jf021064r

Luis P, Kellner H, Zimdars B, Langer U, Martin F, Buscot F (2005) Patchiness and Spatial Distribution of Laccase Genes of Ectomycorrhizal, Saprotrophic, and Unknown Basidiomycetes in the Upper Horizons of a Mixed Forest Cambisol. Microbial Ecology 50(4):570-579

Marguí E, Iglesias M, Queralt I, Hidalgo M (2007) Precise and accurate determination of lead isotope ratios in mining wastes by ICP-QMS as a tool to identify their source. Talanta 73(4):700-709. https://doi. org/10.1016/j.talanta.2007.04.051

Marin B, Valladon M, Polve M, Monaco A (1997) Reproducibility testing of a sequential extraction scheme for the determination of trace metal speciation in a marine reference sediment by inductively coupled plasma-mass spectrometry. Anal ChimActa 342(2-3):91112. https://doi.org/10.1016/S0003-2670(96)00580-6

Monna F, Benothman D, Luck J (1995) Pb isotopes and Pb, Zn and Cd concentrations in the rivers feeding a coastal pond (Thau, southern France): constraints on the origin(s) and flux(es) of metals. Science of The Total Environment 166(1-3):19-34

Morera MT, Echeverría JC, Mazkiarán C, Garrido JJ (2001) Isotherms and sequential extraction procedures for evaluating sorption and distribution of heavy metals in soils. Environ Pollut 113(2):135144. https://doi.org/10.1016/S0269-7491(00)00169-X

Morillo J, Usero J, Gracia I (2004) Heavy metal distribution in marine sediments from the southwest coast of Spain. Chemosphere 55(3): 431-442. https://doi.org/10.1016/j.chemosphere.2003.10.047

Nelms SM, Quétel CR, Prohaska T, Vogl J, Taylor PDP (2001) Evaluation of detector dead time calculation models for ICP-MS. J Anal At Spectrom 16(4):333-338. https://doi.org/10.1039/ B007913H

Nemati K, Abu Bakar NK, Abas MR, Sobhanzadeh E (2011) Speciation of heavy metals by modified BCR sequential extraction procedure in different depths of sediments from Sungai Buloh, Selangor, Malaysia. J Hazard Mater 192(1):402-410. https://doi.org/10. 1016/j.jhazmat.2011.05.039

Novák M, Emmanuel S, Vile MA, Erel Y, Véron A, Pačes T, Wieder RK, Vaněček M, Štěpánová M, Břízová E, Hovorka J (2003) Origin of lead in eight Central European peat bogs determined from isotope ratios, strengths, and operation times of regional pollution sources. Environ Sci Technol 37(3):437-445. https://doi.org/10.1021/ es0200387

Quétel CR, Prohaska T, Hamester M, Kerl W, Taylor PDP (2000) Examination of the performance exhibited by a single detector double focusing magnetic sector ICP-MS instrument for uranium isotope abundance ratio measurements over almost three orders of magnitude and down to $\mathrm{pg} \mathrm{g}^{-1}$ concentration levels. J Anal At Spectrom 15(4):353-358. https://doi.org/10.1039/A907084B

Rauret G, López-Sánchez JF, Sahuquillo A, Rubio R, Davidson C, Ureb A, Quevauviller P (1999) Improvement of the BCR three step sequential extraction procedure prior to the certification of new sediment and soil reference materials. J Environ Monit 1:57-61. https:// doi.org/10.1039/A807854H

Sayer AJ, Cotter-Howells DJ, Watson C, Hillier S, Gadd MG (1999) Lead mineral transformation by fungi. Curr Biol 9:691-694 http:// biomednet.com/elecref/0960982200900691

Schlecht MT, Säumel I (2015) Wild growing mushrooms for the Edible City? Cadmium and lead content in edible mushrooms harvested within the urban agglomeration of Berlin, Germany. Environ Pollut 204:298-305. https://doi.org/10.1016/j.envpol.2015.05.018

Sesli E, Tuzen M, Soylak M (2008) Evaluation of trace metal contents of some wild edible mushrooms from Black Sea region, Turkey. J Hazard Mater 160(2-3):462-467. https://doi.org/10.1016/j. jhazmat.2008.03.020

Shim SM, Oh YH, Lee KR, Kim SH, Im KH, Kim JW, Lee UY, Shim JO, Shim MJ, Lee MW, Ro HS, Lee HS, Lee TS (2005) The characteristics of cultural conditions for the mycelial growth of Macrolepiota procera. Mycobiology 33(1):15-18. https://doi.org/10.4489/ MYCO.2005.33.1.015

SRPS ISO 10390:2007. Soil quality - Determination of $\mathrm{pH}$, Institute of Standardization of Serbia, (2007)

SRPS ISO 11265:2007. Soil quality - Determination of the specific electrical conductivity, Institute of Standardization of Serbia, (2007)

ISO 11271:2002. Soil quality - Determination of redox potential - Field method, International Organization for Standardization, (2002)

Stefanović V, Trifković J, Djurdjić S, Vukojević V, Tešić Ž, Mutić J (2016) Study of silver, selenium and arsenic concentration in wild edible mushroom Macrolepiota procera, health benefit and risk. Environ Sci Pollut Res Int 23(21):22084-22098. https://doi.org/10. 1007/s11356-016-7450-2

Svoboda L, Zimmermannová K, Kalač P (2000) Concentrations of mercury, cadmium, lead and copper in fruiting bodies of edible mushrooms in an emission area of a copper smelter and a mercury smelter. SciTotal Environ 246(1):61-67. https://doi.org/10.1016/S00489697(99)00411-8

Širić I, Kasap A, Bedeković D, Falandysz J (2017) Lead, cadmium and mercury contents and bioaccumulation potential of wild edible saprophytic and ectomycorrhizal mushrooms, Croatia. J Environ Sci 
Health B 52:156-165. https://doi.org/10.1080/03601234.2017. 1261538

Teutsch N, Erel Y, Halicz L, Banin A (2001) Distribution of natural and anthropogenic lead in Mediterranean soils. Geochim Cosmochim Ac 65(17):2853-2864. https://doi.org/10.1016/S0016-7037(01) 00607-X

Thirlwall MF (2002) Multicollector ICP-MS analysis of Pb isotopes using a $207 \mathrm{pb}-204 \mathrm{pb}$ double spike demonstrates up to $400 \mathrm{ppm} /$ amu systematic errors in Tl-normalization. Chem Geol 184(3-4): 255-279. https://doi.org/10.1016/S0009-2541(01)00365-5

Tokalioğlu Ș, Kartal Ș, Elçi L (2000) Determination of heavy metals and their speciation in lake sediments by flame atomic absorption spectrometry after a four-stage sequential extraction procedure. Anal Chim Acta 413(1-2):33-40. https://doi.org/10.1016/S00032670(00)00726-1

Tomašević M, Antanasijević D, Aničić M, Deljanin I, Perić-Grujić A, Ristić M (2013) Lead concentrations and isotope ratios in urban tree leaves. Ecol Indic 24:504-509. https://doi.org/10.1016/j.ecolind. 2012.08.007

Tüzen M (2003) Determination of heavy metals in soil, mushroom and plant samples by atomic absorption spectrometry. Microchem J74(3):289-297. https://doi.org/10.1016/S0026-265X(03)00035-3

Vanhaecke F, Balcaen L, Malinovsky D (2009) Use of single-collector and multi-collector ICP-mass spectrometry for isotopic analysis. J Anal At Spectrom 24(7):863-886. https://doi.org/10.1039/ b903887f

Vukojević V, Đurđić S, Mutić J (2019) Accumulation of U, Th, Pb, V, Rb, and Ag in wild mushroomsMacrolepiota procera (Scop.) Singer from Goč, Serbia. Environ Sci Pollut Res 26(13):13147-13158. https://doi.org/10.1007/s11356-019-04723-Z

White WM, Albarède F, Télouk $\mathrm{P}$ (2000) High-precision analysis of $\mathrm{Pb}$ isotope ratios by multi-collector ICP-MS. Chem Geol 167(3-4): 257-270. https://doi.org/10.1016/S0009-2541(99)00182-5

Wong CSC, Li XD (2004) Pb contamination and isotopic composition of urban soils in Hong Kong. Sci Total Environ 319(1-3):185-195. https://doi.org/10.1016/S0048-9697(03)00403-0

WRB classification (2006) World reference base for soil resources. Food and Agriculture organization of the United Nations, Rome ISBN 92-5-105511-4:1-97. www.fao.org/3/a-a0510e.pdf. Accessed September 2019

Yuan C-G, Shi J-B, He B, Liu J-F, Liang L-N, Jiang G-B (2004) Speciation of heavy metals in marine sediments from the East China Sea by ICP-MS with sequential extraction. Environ Int 30(6):769-783. https://doi.org/10.1016/j.envint.2004.01.001

Zemberyová M, Barteková J, Hagarová I (2006) The utilization of modified BCR three-step sequential extraction procedure for the fractionation of $\mathrm{Cd}, \mathrm{Cr}, \mathrm{Cu}, \mathrm{Ni}, \mathrm{Pb}$ and $\mathrm{Zn}$ in soil reference materials of different origins. Talanta 70(5):973-978. https://doi.org/10.1016/ j.talanta.2006.05.057

Zhang W, Hu Y, Cao Y, Huang F, Xu H (2012) Tolerance of lead by the fruiting body of Oudemansiella radicata. Chemosphere 88(4):467475. https://doi.org/10.1016/j.chemosphere.2012.02.079

Publisher's note Springer Nature remains neutral with regard to jurisdictional claims in published maps and institutional affiliations. 